\title{
Aplikasi Latihan PMR (Progressive Muscle Relaxation) berbasis Arduino UNO pada pencegahan nyeri sendi Lansia
}

\author{
Eqlima Elfira ${ }^{1^{*}}$, Bina Melvia Girsang ${ }^{2}$, Lukman Hakim ${ }^{3}$ \\ ${ }^{1,2}$ Keperawatan Medikal Bedah dan Maternitas, Program Studi Ilmu \\ Keperawatan, Fakultas Keperawatan \\ ${ }^{3}$ Fisika Instrumentasi, Fakultas Matematika dan Ilmu Pengetahuan Alam \\ 1,2,3Universitas Sumatera Utara, Jln. Prof. T'Ma'as No.3 Medan \\ *e-mail : eqlima.elfira@usu.ac.id
}

\begin{tabular}{l} 
Informasi Artikel \\
\hline Diterima Redaksi : 23 Maret 2021 \\
Revisi Akhir : 13 April 2021 \\
Diterbitkan Online : 30 Juni 2021 \\
Kata Kunci: \\
Lansia, Nyeri Sendi, Latihan, progressive muscle \\
relaxation, Arduino UNO
\end{tabular}

\section{PENDAHULUAN}

Usia lanjut adalah tahap akhir perkembangan pada daur kehidupan yang dimana seseorang telah mencapai usia lebih dari 60 tahun [1]. Menurut Dewan Nasional Penuaan bahwa sekitar 92 persen lansia mengalami penyakit kronis. Penyakit kronis yang dialami lansia seperti penyakit jantung, stroke, diabetes dan kanker. Selebihnya masalah Kesehatan mental yang paling besar mempengaruhi lansia. Masalah Kesehatan mental seperti Alzheimer, demensia, dan depresi [2]. Pertambahan usia membuat berbagai masalah Kesehatan yang terjadi pada lansia, dimana sendi akan mengalami kerusakan yang dapat disebabkan oleh beberapa factor. Penyebab nyeri lutut pada lansia dikarenakan kelebihan berat badan atau obesitas, penyakit rheumatoid arthritis, trauma atau kecelakaan. Kemungkinan kejadian nyeri lutut pada lansia dengan usia diatas 65 tahun akan semakin besar [3].

Angka kejadian nyeri lutut di dunia yakni $3,8 \%$ dan terjadi pada daerah pinggul sekitar $0,85 \%$ pada lansia. Sedangkan angka kejadian di Amaerika Serikat meningkat setiap tahunnya sekitar 21 juta [4]. Jumlah
Abstrak

Lansia akan mengalami masalah Kesehatan yang sangat mengganggu aktivitasnya. Di Era tehnologi canggih ini, ide mengembangkan bagaimana mengaplikasikan Latihan progressive muscle relaxation pada lansia dengan tujuan menurunkan kekakuan pada sendi dan mengurangi rasa nyeri didukung oleh tehnologi yang mampu melihat apakah otot mampu melakukan pergerakan dengan baik. Metode dalam kegiatan pengabdian ini melakukan edukasi secara terarah menggunakan buku panduan, lalu melakukan pemeriksaan mendetail seperti tanda-tanda vital, gula darah, kolesterol dan asam urat. Lalu melakukan Gerakan yang disertai pendeteksian otot pada lengan dan kaki lansia. Hasil dari kegiatan, masyarakat mampu melakukan di rumah dengan baik dan menerapkan aplikasi PMR tersebut setiap hari.

lansia di dunia diperkirakan mencapai $22 \%$ dari penduduk lansia atau sekitar 2 miliar pada tahun 2020 dan sekitar $80 \%$ lansia hidup di negara berkembang. Jumlah lansia di seluruh dunia mencapai 1 miliar dalam sepuluh tahun mendatang.

Berdasarkan hasil riset Kesehatan Dasar tahun 2018 menyatakan bahwa angka kejadian nyeri sendi di Indonesia pada tahun 2013 mencapai sekitar 45,59\% [5]. Nyeri sendi menyebabkan inflamasi, kekakuan, pembengkakan, dan rasa sakit pada sendi, otot, tendon, ligament, dan tulang [6]. Penyakit rematik terdiri dari 100 jenis, tetapi bagi masyarakat semua sama saja, dikarenakan memiliki gejala nyeri, kaku, bengkak, pegal-pegal atau kesemutan. Penyakit rematik yang paling sering di temukan di Indonesia adalah osteoarthritis sebesar 50 persen hingga 60 persen. Nyeri sendi diakibatkan karena penggunaan sendi yang berlebihan [6]. Nyeri sendi sering dikatakan sebagai rematik yang merupakan penyakit yang sering ditemukan di seluruh dunia. Nyeri sendi dapat terjadi akibat deposisi kristal monosodium urat (MSU) pada jaringan atau supersaturasi asam urat di 
dalam cairan ekstraseluler yang merupakan pemicu terjadinya inflamasi ${ }_{[7]}$.

Kurang aktivitas fisik merupakan salah satu factor yang mempengaruhi lansia mengalami gangguan muskuloskletal. Salah satu Tindakan intervensi yang dapat dilakukan untuk mengurangi nyeri sendi tersebut dengan melakukan Latihan progressive muscle relaxation ${ }_{[8]}$. Penelitian ini menerangkan bahwa Latihan progressive muscle relaxation memberikan kenyamanan dan mengatasi masalah tidur pada lansia [9]. Latihan ini juga memberikan perubahan pada nilai kadar gula darah, kolesterol dan asam urat lansia setelah melakukan Latihan PMR [10]. Sehingga kemungkinan akan sangat mengurangi nyeri sendi yang dirasakan ${ }_{[8]}$. Di era tehnologi 4.0, kegiatan ini didukung oleh alat berbasis Arduino UNO dimana merupakan alat pendeteksi otot yang membantu dalam melihat perubahan energi kelistrikan pada daerah otot tubuh manusia [11]. Tujuan dari kegiatan pengabdian masyarakat ini adalah membantu lansia dalam mengurangi nyeri sendi dan melakukan deteksi awal terkait masalah otot.

\section{METODE}

Metode dalam kegiatan pengabdian masyarakat ini adalah melakukan pendekatan perorang dikarenakan kondisi covid-19 yang tengah melanda seluruh negeri di seluruh dunia. Pengabdi melakukan pendataan melalui kepala lingkungan dengan mendapatkan data lansia yang berada di lingkungan III kecamatan Medan Sunggal pada tahun 2020. Lalu menemui peserta yang sudah menyetujui untuk dilakukan kunjungan pribadi. Pengabdi menyiapkan materi dan panduan pelaksanaan kegiatan. Adapun proses kegiatan adalah:

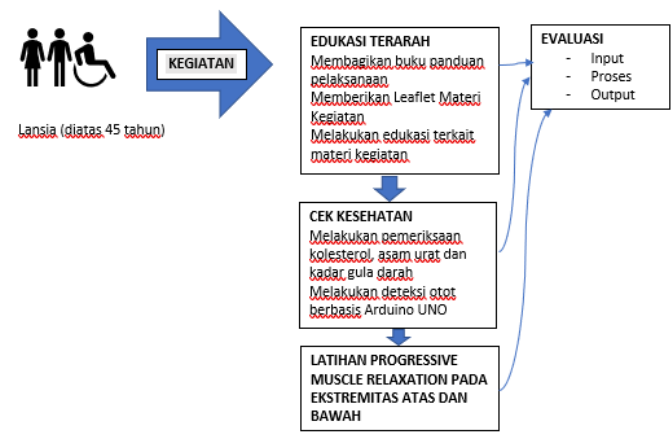

Latihan progressive muscle relaxation dilakukan dengan cara:

1. Melatih otot tangan yang dilakukan dengan cara menggenggam tangan kanan secara bergantian dengan membentuk kepalan. Peserta diminta mengepalkan tangan semakin kuat sambal merasakan sensasi ketegangan saat kepalan tangan perlahan-lahan terbuka.

2. Gerakan melatih otot tangan bagian belakang dengan cara menekuk kedua lengan bagian belakang pada pergelangan tangan sehingga otot di tangan bagian belakang terasa menegang. Jari-jari menghadap ke langit-langit selama kira-kira 8 detik.

3. Melatih otot bisep dengan menggenggam kedua tangan menjadi kepalan dan membawa kedua kepalan ke Pundak sehingga otot biceps menegang. Rasakan ketegangan selama lebih kurang 8 detik dan lepaskan perlahan-lahan.

4. Melatih otot wajah dengan cara mengkerutkan dahi dan alis dalam keadaan mata tertutup.

5. Mengendurkan otot-otot mata diawali dengan menutup mata keraskeras sehingga dapat merasakan ketegangan di sekitar mata dan mengendalikan pergerakan mata.

6. Mengendurkan ketegangan otot rahang dengan mengatupkan rahang diikuti menggigit gigi-gigi sehingga terasa ketegangan di daerah otot rahang.

7. Lakukan hal yang sama pada daerah ekstremitas bawah.

Evaluasi Kembali saat Latihan sudah dilakukan.

Prosedur untuk alat deteksi adalah dengan cara menempelkan dot EMG pada daerah otot yang akan dilakukan pemeriksaan, lalu alat dihubungkan pada Bluetooth HC-05 setelah itu aplikasi akan mendeteksi apakah otot mengalami masalah pada otot terlihat pada frekuensi yang dihasilkan.

\section{HASIL DAN PEMBAHASAN}

Pelaksanaan kegiatan pengabdian dimulai pada tanggal 21juli 2020 di Klinik Ummi Pratama, Lingkungan II, Kecamatan 
Medan Sunggal dengan jumlah peserta 19 orang lansia. Pelaksanaan kegiatan dilakukan sesuai prosedur tetap coronary disease 2019 sehingga pelaksanaannya membutuhkan waktu sebulan setiap hari. Namun pada pembukaan kegiatan dilakukan pada tanggal 21 juli 2020 oleh kepala klinik dan dibantu beberapa pengabdi. Peserta ratarata berusia diatas 45 tahun, mayoritas ibu rumah tangga dan bersuku Aceh.

Tabel 1.

Karakteristik usia, pekerjaan dan suku lansia yang mengikuti kegiatan

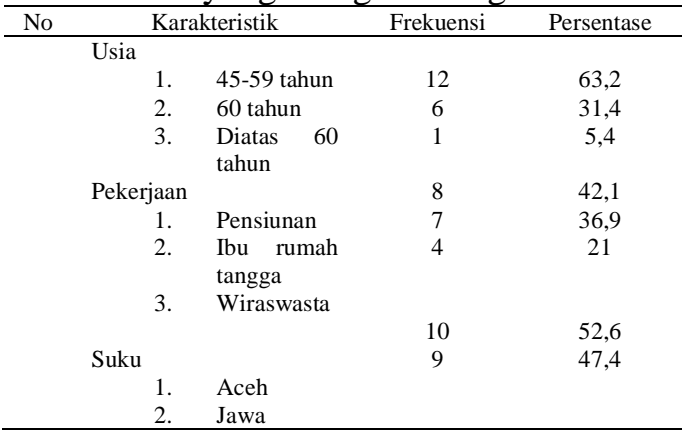

Pada table 1 ini menjelaskan bahwa usia yang paling dominan mengikuti kegiatan adalah usia 45-59 tahun sekitar 63, 2 persen sebanyak 12 orang dengan pekerjaan pensiunan sebanyak 8 orang sekitar 42,1 persen dan bersuku aceh sebanyak 10 orang sekitar 52,4 persen. Kegiatan ini berjalan dengan baik dengan peserta yang kooperatif pada saat pelaksanaan.

Tabel 2.

Skala pengukuran nyeri berdasarkan Verbal Rating Scale (VRS)

\begin{tabular}{ll}
\hline Skala & Tanggapan nyeri \\
\hline 0 & Tidak nyeri \\
1 & $\begin{array}{l}\text { Nyeri dilaporkan hanya sebagai tanggapan atas } \\
\text { pertanyaan, tanpa tanda-tanda perilaku }\end{array}$ \\
2 & $\begin{array}{l}\text { Nyeri dilaporkan sebagai respons dalam } \\
\text { pertanyaan dan disertai dengan tanda perilaku, }\end{array}$ \\
3 & $\begin{array}{l}\text { atau nyeri secara spontan } \\
\text { Respon vernal yang kuat diserta wajah meringis, } \\
\text { penarikan tangan atau air mata. }\end{array}$ \\
\hline
\end{tabular}

Tabel 3

Hasil Verbal Rating Scale (VRS) setelah dilakukan Latihan progressive muscle

\begin{tabular}{ccc}
\multicolumn{3}{c}{ relaxation $(\mathrm{PMR})$} \\
\hline Skala & Frekuensi & Persentase \\
\hline 0 & 7 & 36,9 \\
1 & 8 & 42,1 \\
2 & 4 & 21 \\
\hline
\end{tabular}

Dari table 3 ini dapat dievaluasi bahwa Latihan PMR ini sangat membantu lansia dalam mengurangi nyeri sendi sebanyak 7 orang sekitar 36,9 persen mengalami perubahan dalam waktu sebulan.
Tabel 4. Hasil deteksi otot berbasis Arduino UNO

\begin{tabular}{lll}
\multicolumn{3}{c}{ Arduino UNO } \\
\hline & Frekuensi & Persentase \\
\hline Normal & 16 & 84,2 \\
Abnormal & 3 & 15,8 \\
\hline Dari hasil table
\end{tabular}

Dari hasil table 4 ini menjelaskan bahwa otot mengalami perubahan Kembali ke kondisi normal sebanyak 16 orang.

Hasil penelitian C. L. Baird and L. Sands (2004) menyatakan bahwa Latihan PMR dapat mengurangi nyeri dan kesulitan mobilitas [12]. Latihan Progressive Muscle Realxation (PMR) merupakan teknik relaksasi mendalam yang telah terbukti dapat menurunkan tingkat stres, kecemasan, dan nyeri kronis [13]. Latihan ini juga mampu meningkatkan status fungsional lansia [14].

\section{KESIMPULAN}

Kesimpulan dalam kegiatan pengabdian masyarakat ini adalah:

1. Kegiatan membutuhkan pendataan survey awal jumlah lansia

2. Kegiatan membutuhkan peserta yang bersedia dalam kegiatan rutin

3. Kegiatan pengabdian ini dimulai dengan melakukan edukasi, pemeriksaan dan Latihan

4. Kegiatan ini membutuhkan evaluasi

\section{SARAN}

Lansia yang melakukan kegiatan ini merasa sangat membantu dan mengalami peningkatan pengetahuan tentang Latihan progressive muscle relaxation (PMR) berbasis Arduino UNO. Lansia juga merasa memiliki pengetahuan bagaimana cara mengatasi nyeri sendi di rumah sesuai panduan yang sudah diberikan.

\section{UCAPAN TERIMA KASIH}

Ucapan terima kasih kepada Lembaga Pengabdian Masyarakat Universitas Sumatera Utara. Ucapan terima kasih disampaikan kepada pihak-pihak yang membantu pelaksanaan PKM.

\section{REFERENSI}

[1] R. S. Maryam, M. F. Ekasari, Rosidawati., A. Jubaedi, and I. Batubara, Mengenal Usia Lanjut dan Perawatannya. 2008. 
[2] I. Soejoethi, "5 Masalah yang Selalu Dihadapi oleh Lansia," ayojakarta.com, 2019. https://www.ayojakarta.com/read/20 19/08/22/3333/5-masalah-yangselalu-dihadapi-oleh-lansia-kotakmasuk (accessed Mar. 22, 2021).

[3] Flex Free, "Nyeri Lutut pada Lansia," flexfreeclinic.com, 2020. https://flexfreeclinic.com/artikel/det ail/283?title=nyeri-lutut-pada-lansia (accessed Mar. 22, 2021).

[4] A. Susarti and M. Romadhon, "Faktor-Faktor Yang Berhubungan Dengan Kejadian Rheumatoid Arthritis Pada Lansia," J. 'Aisyiyah Med., vol. 4, no. 3, 2019, doi: 10.36729/jam.v4i3.202.

[5] Kementerian Kesehatan Badan Penelitian dan Pengembangan Kesehatan 1, "HASIL UTAMA RISKESDAS 2018 Kementerian," Kementrian Kesehat. Republik Indones., pp. 1-100, 2018, Accessed: Mar. 22, 2021. [Online]. Available:

http://eprints.poltekkesjogja.ac.id/36 41/4/Chapter2.pdf.

[6] E. (Puslitbang B. dan F. B. P. dan P. K. Nainggolan and D. K. R. Kesehatan, "Prevalensi dan Determinan Penyakit Rematik di Indonesia," Maj. Kedokt. Indones., p. 59, 2009.

[7] Meliny, Suhadi, and M. Sety, "Analisis Faktor Risiko Rematik Usia 45-54 Tahun di Wilayah Kerja Puskesmas Puuwatu Kota Kendari Tahun 2017," J. Ilm. Mhs. Kesehat. Masy., vol. 2, no. 2, p. 3, 2018.

[8] E. Wijaya and T. Nurhidayati, "Penerapan Terapi Relaksasi Otot Progresif Dalam Menurunkan Skala Nyeri Sendi Lansia," Ners Muda, vol. 1, no. 2, p. 88, Aug. 2020, doi: 10.26714/nm.v1i2.5643.

[9] D. N. T. Idris and K. Astarani, "Therapy of Effective Progressive Muscle Relaxation to Reduce Insomnia in Elderly," Str. J. Ilm. Kesehat., vol. 8, no. 2, pp. 165-171, 2019, doi: 10.30994/sjik.v8i2.219.

[10] E. Elfira, "EFFECT OF PROGRESSIVE MUSCLE RELAXATION EXERCISE
BASED ON ARDUINO UNO ON BLOOD SUGAR, CHOLESTEROL AND URID ACID LEVELS IN THE ELDERLY," Nurse Heal. J. Keperawatan, vol. 9, no. 2, pp. 211218, Dec. 2020, doi: 10.36720/nhjk.v9i2.193.

[11] F. T. Abyanto and F. B. Setiawan, "DETEKSI KEJENUHAN SELURUH OTOT MANUSIA MENGGUNAKAN SENSOR EMG BERBASIS MIKROKONTROLER ARDUINO UNO," 2019, pp. 69-74, doi: 10.5614/sniko.2018.11.

[12] C. L. Baird and L. Sands, "A pilot study of the effectiveness of guided imagery with progressive muscle relaxation to reduce chronic pain and mobility difficulties of osteoarthritis," Pain Manag. Nurs., vol. 5, no. 3, pp. 97-104, Sep. 2004, doi: 10.1016/j.pmn.2004.01.003.

[13] A. Wenzel, "Progressive Muscle Relaxation," in The SAGE Encyclopedia of Abnormal and Clinical Psychology, 2017.

[14] E. Elfira, N. Nurbaiti, and R. D. Tumanggor, "Effect of Progressive Muscle Relaxation on the Functional Status of the Elderly in the Integrated Services Unit of the Elderly Binjai," Nurs. J. Respati Yogyakarta, vol. 7, no. 2, pp. 126131, 2020, Accessed: Mar. 23, 2021. [Online]. Available:

http://nursingjurnal.respati.ac.id/inde x.php/JKRY/search/authors/view?fir stName $=$ Eqlima\&middleName $=\& l a$ stName $=$ Elfira\&affiliation $=$ Universi tas Sumatera Utara\&country=. 